Teague, Elizabeth. 1993. "Ural Leader Calls New Job 'A Protest." In Radio Free Europe, November 12.

Teague, Elizabeth and Slater, Wendy. 1993. "New Chief Editor for Pravda." In Redio Free Europe 209, October 29.

Tolz, Vera. 1993. "Yeltsin Meets Media Chiefs." In Radio Free Europe 214, November 8, a. . 1993. "Presidential Decree Dissolves Ural Republic." In Radio Free Europe, November $8, b$.

1993. "Comments on the New Draft Constitution." In Redio Free Europe, November 12.

1993. "Yeltsin Promises to Guarantee Press Freedom." In Radio Free Europe 204, October 22, a.

- 1993. "Liberal Press Expresses Doubt About Fairness of Election Campaign." In Radio Free Europe 204, October 22, b.

. 1993. "Leader of Republican Party Comments on Elections." In Radio Free Europe 204, October 22, c.

The Toronto Star. 1993. "Yeltsin a Failure, Gorbachev says." March 26.

Vizhutovich, Valeriy. 1993. "Ministerstvo Bezopasnostl Obyazano Garantiroat Bezopasnost Gosudarstva i Ego Grazhdan (The Ministry of Security Has a Duty to Guarantee Security of the State and its Citizens)." In Izvestia, May 7.

Wishnevsky, Julia. 1993. "Independent Media in Jeopardy?" In Radio Free Europe 210, November 2 .

. 1993. "Draft Law Gives Extensive Investigative Powers to Former KGB." In Radio Free Europe 89, May 11.

Yasmann, Victor. 1993. "Corruption in Russia: A Threat to Democracy?" In Radio Free Europe Research Report 2(10), March 5. •

Continued from page 2.

\section{References}

Crow, Suzanne. 1993. "Helsinkj Watch Letter on Peacekeeping Violations." In Radio Free Europe, November 2.

- 1993. "Kozyrev on Maintaining Conquests." In Radio Free Europe, October 8.

Eggert, Konstantin. 1992. "Russia in the Role of 'Eurasian Gendarme'?" In Izvestia, August7.

Gray, John. 1993. "President Pays the Price for Russian Army Loyalty." In The Globe and Mail, October 7.

Markus, Ustina. 1993. "Zlenko Rejects Special Status for Russian Forces." In Radio Free Europe, October 13.

UNIAR. 1993. "Report on Russian Use of Chemical Weapons." In FBIS-SOV-93-154, August 12.

Whitney, Craig R. 1993. "Worried Anew, Europe Asks How Best to Keep the Peace." In The New York Times, October 31. 。

\title{
Nationalism and the Violation of Minority Rights in Latvia
}

\author{
Alexander Benifand and Tanya Basok
}

Nationalism, which inspired the struggle for Latvian independence, remains a strong force in this country. In practice, nationalism has translated into laws and policies that often violate the rights of the non-Latvian population. Against a background of economic crisis and rising crime, nationalist ideas are gaining popular support as the disgruntled population attempts to find a scapegoat for emerging domestic problems.

\section{Economic Instability}

Privatization has progressed slowly in Latvia. Only 7 percent of state property was privatized in 1992 . Industries are experiencing tremendous losses and are in need of restructuring and investment. Many factories do not even have enough money to pay wages (Petersons 1993, February 18). In 1992, industrial production in Latvia dropped by 31.5 percent over the previous year, while consumer prices rose by 1,051 percent (Bungs 1993, January 15).

In 1993, industrial production continued to decline. The chairman of the Latvian statistics office, Gunars Baltins, reported that industrial production in January 1993 was 8 percent lower than in December 1992 and 45.6 percent lower than in January 1992 (Girnius 1993, February 10). In 1992, 33,200 persons, or about 2.3 percent of the economically active population, were officially unemployed. The unemployment problem was further aggravated by the existence of another 44,300 persons who were laid off or had their working hours shortened (Bungs 1993, January 15). According to the Statistics Committee of the Republic of Latvia, 83 percent of Latvian residents were living below subsistence levels in 1992 (Riga Leta 1993, September 23).

\section{Rising Crime}

As growing numbers of people begin to experience economic hardships, many are resorting to illegal livelihoods. In 1992, crime increased throughout the Baltic states. However, of all the Baltic states, Latvia had the highest crime rate (Girnius 1993, March 1). Crime rose by 48 percent in 1992 over the previous year. Of the 61,900 registered crimes in 1992, the vast majority were cases of either theft or robbery; some 234 cases were murders or attempted murders (Bungs 1993, January 15).

\section{Political Situation}

The Latvian government has moved to the centre of the political spectrum. In the June 1993 elections, victory was won by the moderate liberal forces. The Latvian Path bloc headed by Anatolis Gorbunovs, Chairman of the Supreme Soviet, won the most votes (32.4 percent), followed by the radical Movement for National Independence (13.35 percent), the Peasant Union Party (10.64 percent), and the Equality Movement (5.77 percent), led by Alfreds Rubiks, the former First Secretary of the CP Latvia Central Committee.

Conservative Communist organizations still maintain a high profile. During the recent siege of the Russian Parliament in Moscow there were reports that these forces were planning a similar coup attempt. If the antiYeltsin opposition in Moscow had been victorious, members of the OMON (special purpose militia detachment) from the Latvian capital Riga, and the "Dniester Republic" had apparently planned to kidnap Latvian leaders in the hope of trading them for Alfreds Rubiks, currently on trial for anti-Latvian activities. To neutralize

Refuge, Vol. 13, No. 7 (November-December 1993) 
the political opposition, on October 6th the Latvian government banned three pro-Communist organizations (Latvian Union of Communists, Union to Secure Veterans' Rights and Latvian Association of Russian Citizens) for "22 acts of conspiracy" (Girnius 1993, October 7). This measure could potentially heat up what has so far been a rather peaceful struggle for power in Latvia.

\section{Nationalism and Violations of 'Minorities' Rights}

The popularity of Latvian nationalism and anti-Russian sentiments are both responses to the past subordination of the republic by Moscow, and to Russia's present interference with Latvian domestic life. The Russian-speaking population, most of whom migrated to Latvia after 1940 (the year of the Soviet invasion), is identified with Russian imperialism. The national radicals, such as members of the Citizen's Congress and the Lettish National Tevzeme Alliance, have adopted the toughest stance. They are demanding Latvia's complete "decolonization" and "de-occupation," implying, as was bluntly declared at the Tevzeme's December 1992 Congress, the repatriation of the "occupants" either to their ethnic homes, or to some third country. In their appeal to the audience, they declared: "Register colonialists only at railway stations!" (Myalo 1993). An article arguing against granting civil rights to Russians appeared in Pavalsinieks Daily; "Nothing can save the Latvian nation from destruction if Russian colonialists are granted citizenship," the author argued (Kolmanson 1993, April 11). These nationalist sentiments find fertile soil at the highest levels of the state. The head of the Latvian state declared in a short interview before departing for New York that, "those who occupied and had incorporated Latvia and find Latvia's independence unacceptable, will have to leave" (Myalo 1993).

In their desire to purge themselves of the remnants of their colonial past, Latvian political leaders have introduced laws and policies which violate the rights of the Russian-speaking population, including ethnic Russians, Jews, Tatars and members of other ethnic groups. According to the Chair of the Latvian Parliament, Anatolis Gorbunovs, Parliament endorsed Latvia's new system of ethnic separation. Under this system (enacted by Parliamentary resolution, but yet to be passed as law), Latvian citizenship will be granted only to those people who can pass a Latvian language test and show that their parents or grandparents held citizenship as of June 17, 1940 - the day of the Soviet invasion. The new proposed restrictions may ultimately make it illegal to own property or open a bank account, and will make it difficult for non-citizens to hold job or obtain university degrees. The Movement for Latvia's National Independence (with 15 seats in the Parliament), announced its own draft of the law on citizenship. Their proposed law would immediately grant citizenship to ethnic Latvians, members of the Latvian citizens' families and foreigners who legally arrived in Latvia before it joined the Soviet Union. The draft law also proposes that most former Soviet citizens be granted Latvian citizenship on the basis of annual naturalization quotas not exceeding 10 percent of annual population growth (FBIS 1993, September 15).

According to Edward Barnes, these proposed measures are intended to force Russians to return to Russia. This would also disenfranchise an estimated 95 percent of the nation's Jews, most of whom came to Latvia after 1940 (Barnes 1992). The CSCE commissioner for national minority issues, Max Van der Stoel, noted that the status of a resident whose future in Latvia is not yet decided is also a matter of some concern (Bungs 1993, January 22). He argued that "Russian-speaking people living in Latvia who have been sent to Latvia in accordance with the central planning policy of the former USSR are merely victims of the Soviet system in the same way that Latvians are" (Radio Riga Network 1993, September 15). Van der Stoel called on the Latvian Government to quickly adopt a more liberal law on citizenship in order to stabilize Latvian politics ( $R a$ dio Riga Network 1993, September 14).

The 90,000 strong Russian-speaking population was deprived of the right to vote in the June 1993 parliamentary election, although the Latvian Sejm has been compelled to permit them to vote in local elections. However, Eduard Smekhov, leader of the Russian community in Latvia, believes that Russians will be ousted from Latvia by the time of the elections, given that many of them will have lost their temporary resident status by then (Yemelyanenko 1993, June 11).

A report on the three Baltic states, published by the State Department, describes the unresolved status of the Russian residents as a cause of "exacerbated tensions" among ethnic groups there. The report cites the new language law as a potential lever for discrimination in jobs and elsewhere (Trumbull 1993, January 21).

According to media reports, discrimination against non-Latvians is widely practised in all spheres of Latvian life. "The discrimination begins in kindergarten where Russians have to pay more for their children," observes one Russian emigrant from Latvia who was forced to leave his position as a technician and work as a mechanic (Pushkar 1992, August 11). The New Times magazine has published several letters documenting such discrimination. One of them reads:

My father was born in Latvia before the 1940 s and I have all the papers needed to confirm that. However at the registration centre in Jaunolaine I was asked to describe properties' privately owned by my father.' When I could not give a detailed account, I was told citizenship would be denied me (Myalo 1993).

Another letter says: "I am Lettish by birth, but I will not be granted citizenship because my husband is a Soviet Army colonel" (ibid.).

Given this situation, it is no wonder that when polled by the All-Russian Centre for Public Opinion Research, 75 percent of Russian-speaking respond- 
ents said they believe that over the last two to three years, the attitude toward them has worsened in Latvia; 32 percent of the respondents believe that a mass exodus of Russian-speaking people from Latvia will begin in the near future (Bungs 1992, December 6).

Russian political leaders have expressed serious concern about the violation of minority rights in the Baltic states. Speaking at a closed meeting of Foreign Ministers of the Council of Baltic Sea States on March 16, 1993, A. Kozyrev, Russian Foreign Minister, said he would not sign a communique with the other Baltic states unless they appointed a commissioner to protect the rights of ethnic minorities. Kozyrev likened the plight of Russian minorities in the Baltic to the current situation in the former Yugoslavia (Crow 1993, March 17). The Russian Parliament's Committee on Human Rights has accused Latvia of violating the rights of minorities, and called upon the country's Parliament to make changes in their legislation. In the opinion of the Committee, Latvia has established "a regime unfavourable even for those members of the Russian-speaking population who intended to assimilate into the new state's legal environment." The Committee drew attention to the repercussions of the undefined status of, and discrimination against, the Russian-speaking populations of Latvia, mentioning more specifically the intensification of chauvinistic and nationalistic forces in Russia and Latvia, which could threaten regional security.

The committee appealed to Latvian legislators to take the following actions:

abolish state language examinations for those over 50 years old; eliminate any requirements for command of the state language; reduce settlement requirements in Latvia to five years and generally redefine "permanent residency" in Latvia; reconsider and reduce the numbers of people who cannot receive citizenship; and confer citizenship upon children born to parents without citizenship (Moscow Baltfax 1993, February 25).
Moscow has turned the issue of protecting the rights of the Russian-speaking population into a precondition for the withdrawal of its troops. In an interview with the German agency, DPA, The Russian Ambassador to Latvia, Alexandr Rannikh criticized Latvia for committing innumerable injustices against the Russian-speaking minority and its electoral law for violating human rights and announced that if Latvia continues to create complications in bilateral relations, Russia will not be able to withdraw its troops by the end of 1994 as planned.

In its turn, the presence of 27,000 Russian troops, and Russian intelligence (Bungs 1993, January 13) is a perpetual irritant to the Latvian population who regard it as interference in Latvia's domestic affairs. This fuels nationalist sentiments both in the government and among the population at large. Latvia took its running dispute with Russia to the United Nations on September 29, 1993, where it demanded the immediate withdrawal of Russian troops and defended its controversial citizenship laws. Latvian President, Guntis Ulmanis, told the General Assembly that the presence of foreign forces threatened regional stability, degraded the environment, and discouraged badly-needed foreign investment. The President dismissed charges that efforts to protect the slim majority of ethnic Latvians (which he estimated at 52 percent) amounted to discrimination against Russians, Ukrainians and others (Reuters 1993, September 29).

The Latvian Parliament voted to remove the remains of hundreds of Red Army soldiers from a military cemetery in Riga, saying that "their presence offends nationalist sentiments in the former Soviet republic" (Toronto Star 1993, February 3). In turn, Leonid Mayorov, the commander-in-chief of the Northwestern Military Group Forces of the Russian Army, accused the Latvian Home Guard of repeated provocations against Russian military personnel, and he sent Latvian Supreme Council Chairman, Anatolijs Gorbunovs, a letter containing a warn- ing that Russian military personnel stationed in Latvia may be ordered to arm themselves when moving around Latvian territory (FBIS, June 2). While Russia refuses to withdraw its troops until the rights of the Russian-speaking population are protected, the Latvian authorities are reluctant to extend full citizenship to these people as long as the Russian military is stationed in Latvia. Representatives of the Fatherland and Freedom faction, who have six of Parliament's one hundred seats, have stated that the naturalization of former Soviet citizens was impossible before the Russian troops' complete removal from Latvia. This faction believes that former Soviet citizens should be treated as "illegal migrants," and therefore, the world community should help Latvia to have them repatriated to Russia (FBIS 1993, September 15).

Russian ultra-nationalists continually threaten the independence of Latvia by claiming that the predominately Russian districts should become part of Russia (Bungs 1992, December 7). This intensifies the backlash against the Russian-speaking population, including Jews.

Having analyzed the situation of Russian-speaking people in the Baltic republics, a well-known American political scientist, Francis Fukuyama, warned the United States in his article published in the New York Times, that unless the United States is willing to defend the rights of Russian-speaking minorities in the Baltic countries, there will be another hot spot appearing on the map of Europe (Volsky 1993).

Following a recent visit to Latvia, the U.S.-based Helsinki Watch organization, on October 29, 1993, gave Premier Valdis Birkavs a list of violations and irregularities in the implementation of human rights. Baltic media reported that most of the criticism had to do with the registration of nonLatvians, especially members of the Russian military, former members of the Soviet army and their families, by the Citizenship and Immigration Department from March 1992 to March 1993. Helsinki Watch also objected to 
recent legislation stipulating that noncitizens in Latvia receive only 90 percent of the state pension (Bungs 1993, November 2).

\section{Anti-Semitism and Ultra-Nationalism}

According to senior Life correspondent, Edward Barnes, "a resurgent antiSemitism is forcing the Jews of Latvia to run for their lives" (Barnes 1992). ${ }^{1}$ He claims that neo-Nazis are becoming increasingly visible in Latvia. Among the 15,000 member armed Latvian police, for instance, there are two units composed of "Old Warriors," former members of the Waffen SS. Some of them have been training in the farm country outside Riga. For six weeks they lived together in a dormitory and filled their days with marching, target practice, war stories and new politics. Even more disconcerting for Jews, he insists, is the sight of the Aizsargi, the paramilitary group that helped the Nazis in their attack on Riga and killed many Jews. This group, which can be seen patrolling the streets and marching in rallies, claims to have 14,000 members (Barnes 1992).

Anti-Semitism is becoming more overt. Many Latvian Jews experience personal confrontations with members of Old Warriors and their supporters who tell them to "get out" (Barnes 1992). During a world congress of Jews in Riga, commemorative slabs installed at a site in Bikernieks forest where 46,500 Jews had been shot to death 50 years ago, were desecrated. Swastikas and inscriptions "Juden frei" (free from Jews) were drawn on the slabs. ${ }^{2}$ Schools present Jews in a derogatory light. A new Latvian history textbook for 12-year-olds gives a false picture of the role of the Jews in the history of Latvia. It mentions, for example, that the organizer of Stalin's violence in Latvia was Simons Schustins, of Jewish background (American Association of Russian Jewry 1992, November).

A number of recent beatings of Jews, two of which resulted in death, have alarmed the Jewish community in Riga. In the case of the beating death of 53-year old Semen Riftin, police explained to the family that they could find no witnesses, no evidence, and no motive, and, therefore, had no practical reason to open an investigation of the case. In a police report handed to the victim's wife, it was stated that he had fallen from a height of five feet and died of his injuries, contrary to what the doctors and a few of the investigating officers had told her (Monitor 1993).

Anti-Semitic statements are even made by People's Deputies. One of them, Juris Debelis, has been cited accusing "Russian Yidloving journalists" of causing the country's hardships. Another People's Deputy, Juris Bojars, said that Latvians should never apologize to Jews for the injustice done to them because Jews in the Soviet Government assisted in deportations and massacres of Latvians in the past (Koval 1993).

\section{Notes}

1. On December 2, 1992, Ojars Kainins, Minister Counsellor of the Embassy of Latvia, wrote a letter to Pamela Cohen, National President of the Union of Councils for Soviet Jews, in which he catalogues, "the errors, distortions and unsupported claims" made by Barnes in his article. Latvian Ambassador to the UN Aivars Baumanis also stated in an interview that the Life correspondent had been used as "a pawn in Russian propaganda." Latvian media made considerable efforts to refute or at least downplay the article. However, an editor's note in the March issue of Life affirms that the magazine, "stands by its story" (Litvinova 1993, April 2).

2. Latvian Parliament Chief, Anatolijs Gorbunovs, described this as an act of vandalism. On June 11, 1993 he apologized to the Jews for the crime (ITAR-TASS 1993, June 12).

\section{References}

American Association of Russian Jewry. 1992. Information Bulletin 9/10, November.

Barnes, Edward. 1992. "Soon They Will Come for Us." In Life 12.

Bungs, Dzintra. 1993. "Helsinki Watch on Human Rights in Latvia." In Radio Free Europe 210, November 2.

- 1993. "CSCE Commissioner on minority rights in Latvia." In Radio Free Europe 14, January 22.

1993. "Inflation Up, Production Down in Latvia." In Radio Free Europe 9, January 15. . 1993. "Figures on Soviet Military Presence in Latvia." In Radio Free Europe 7, January 13.
Bungs, Dxintra. 1992. "Zhirinovsky's views of the Baltic States." In Radio Free Europe 234, December 7.

- 1992. "Majority of Russians in Latvia want Latvian citizenship." In Radio Free Europe 232, December 6.

Crow, Suzanne. 1993. "Kozyrev demands minorities commissioner." In Radio Free Europe 52, March.

Foreign Broadcasters Information Service (FBIS). 1993. "Coundl of Europe to Examine Draft Citizenship Law." FBIS-SOV-93-177, September 15.

. 1993. "Russian Chief Warns Troops May Be Armed to Prevent 'Provocations'." FBIS SOV-93-104, June 2.

Girnius, Saulius: 1993. "Latvia Bans pro-Communist Organizations." In Radio Free Europe, October 7.

—. 1993. "Crime in Baltic States in 1992." In Radio Free Europe 40, March 1. - 1993. "Decline in Latvian industrial production." In Radio Free Europe 27, February 10.

ITAR-TASS. 1993. "Jewish Memorial Vandalized; Gorbunovs Apologizes." June 12.

Kolmanson, D. 1993. Address to The Union of Councils for Soviet Jews 12, April 5-11.

Koval, Leonid. 1993. "Update on Anti-Semitism in Latvia." Monitor 4, October 1992 February 1993.

Litvinova, Irina. 1993. "How Latvia Combats Discomforting Information." In Izvestia, April 2.

Monitor. 1993. "Jews in Riga Victims of Deadly Assaults." Vol. 4, October 1992 - February 1993.

Moscow Baltfax. 1993. "Latvia, Estonia Accused of Human Rights Violations." February 25.

Myalo, Ksenia. 1993. "Is it easy to be a Russian in Riga?" In New Times Intermational 7.

Petersons, Agris. 1993. "Latvia: No Economic Upheavals in the Offing." In Moscow News 8 February 18

Pushkar, Arnold. 1992. "The Seventh Wave of Emigration Could be the Most Massive in Russia's History." In Izvestia, August 11.

Radio Riga Network. 1993. "CSCE Envoy Discusses Rights for Russian-Speakers." September 15.

. 1993. "Ulmanis, CSCE Official Discuss Rights Issues." September 14.

. 1993. Untitled, May 25. In FBIS-SOV-93100, May 26.

Reuters. 1993. “Latvia Seeks UN Backing for ExSoviet Troop PullOut." United Nations, September 29.

Riga Leta. 1993. "83\% of Residents Said Below Subsistence Wage Level." In FBIS-SOV-93183, September 23.

The Toronto Star. 1993. "Latvia to Remove 'Offensive' Remains." February 3.

Trumbull, Charles. 1993. "...And the Baltics." In Radio Free Europe 13, January 21.

Volsky, Dmitry. 1993. "Baltic States: High or Low Tide?" In New Times 20.

Yemelyanenko, Vladimir. 1993. "The 'Russian' Question as the First Touchstone." In Moscow News 24, June 11. • 